\title{
Why I Am a Salafi
}

\author{
Michael Muhammad Knight \\ Berkeley, CA: Soft Skull Press, 2015. 378 pages.
}

Anyone who was not familiar with Michael Muhammad Knight's oeuvre and picked up his Why I Am a Salafi based upon the title, thinking it would be a straightforward explanation and defense of Salafism, would be quickly disabused of that impression. Knight begins this memoir/theological exploration/postmodern deconstruction with an extended anecdote about his experience of praying at a Los Angeles mosque while coming down from a drug-induced hallucination brought on by his intentional consumption of Amazonian ayahuasca tea, and the book gets stranger from there. This transgressive episode of praying while high becomes a touchstone for Knight in his rethinking of his own Muslimness, the origins of the Islamic tradition, and his life-journey through a variety of controversial and eccentric communities on the fringes of the American Muslim community.

In Knight's previous body of work-from his 2004 novel The Taqwacores (Soft Skull Press) about punk-rocking, countercultural American Muslims to his insider-white-man narrative of an esoteric offshoot movement of the Nation of Islam in Why I Am a Five Percenter (Penguin, 2011)- he has long cast himself as an experimental Muslim writer challenging established traditions and organized religion of all kinds. Like some of his other books, Why I Am a Salafi is difficult to categorize. Framed around Knight's odyssey within American Islam and the diffuse trends that contributed to the development of his distinct perspective, it is part religious autobiography, part analysis of the nebulous concept of Salafism, and part therapy session. Indeed, drawing upon his well-established tendency toward bucking trends and upsetting orthodoxies, Knight quips that in the progressive Muslim circles he tends to run in, labeling himself a Salafi could itself be a form of rebellion. "Depending on whom you want to irritate, Salafis could look like the new punk rock" (29).

But Knight's book is not entirely made up of recounting hallucinations and sticking a finger in the eye of confident Islamic subcommunities. What he endeavors throughout is a personal reconsideration of Islam: one that allows him to notionally remain a Muslim despite the many contradictions and inconsistencies he detects among the diverse forms of Islam that he himself has belonged to. And he uses Salafism, with the movement's desire to return to authentic Islam and its focus on direct readings of the Qur'an 
and the Hadith, as a means of decentering any assertive definition of Islam. This, of course, is not how most people, or, most Salafis themselves, think of Salafism, yet as he puts it, "my Salafism trolls everyone, becoming the big No to all claims of apprehending the truth of the Qur'ann or the earliest Muslims" (33). Knight reappropriates Salafism as a mode of post-structuralist epistemic critique: how does anyone know what authentic Islam was or is and who gets to say how Islam should be practiced?

There are several sections of Why I Am a Salafi that are quite insightful and interesting for their forthright, albeit polemical, internal explorations of the complexities of Islam's diverse manifestations. The second chapter, "Return to Pamphlet Islam," reflectively dismantles the culture of simplistic apologetic summaries of Islam that circulated through the American Muslim community into which Knight converted in the 1990s. The third chapter, "Disconnected Letters," revisits the longstanding hermeneutical principle of distinguishing between muhkamät (clear verses) and mutashābihāt (unclear or allegorical verses) in the Qur'an. Through a close reading of the Islamic tradition's treatment of this distinction, Knight's quibble is less with these categories and more with their application: can't one find ambiguities and underlying questions in any verse, in any language act?

While maintaining this mode of epistemological skepticism, chapters 4 and 5 ("Digging through the Crates" and "Ibn Hanbal Action Figure!") excavate the historical origins of the framework that undergirds Salafism. Knight gives an accessible summary of the process behind the vast medieval Hadith corpus that became the textual matrix for interpreting the Qur'an in the Sunni tradition. He introduces this section with an epigraph from Derrida_ "The archivization produces as much as it records the event"which serves as a fitting summary for Knight's understanding of the Hadith: they enshrine visions of Muhammad and his companions that might be authentic but are so kaleidoscopic and enmeshed in medieval debates as to be endlessly re-arrangeable. He profiles Ahmad ibn Hanbal, a stalwart early-medieval defender of the Hadith, as an intellectual ancestor to the Salafis. What Knight finds compelling about Ibn Hanbal is his willingness to accept, without rationalizing or prevarication, challenging sayings from the Hadith and verses of the Quran (bi-lā kayf- "without asking how"), which Knight sees as a parallel to postmodern suspension of meaning in a text. He seeks to formulate a vision of Islam where such texts can be played with, experienced, and even enacted through practices like prayer without worrying about their intrinsic truth claims or meanings. 
Chapter 6, "Salafi Planet," probably represents Knight's most important academic contribution in the book. He intriguingly situates global Salafism historically against the backdrop of the intellectual hegemony of Western Protestantism and in parallel to modern movements within the other "world religions" to recover the original or authentic teachings of the Buddha or the golden age of Hinduism. For Knight, Salafism's modern claims to retrieve the pristine premodern version of Islam is of a piece with these other counter-colonial recovery and rethinking efforts. The latter half of the chapter offers a discerning overview of how various strands of Islam in modernity (al-Afghani and 'Abduh's modernism, Wahhabi revivalism, the disintegration of the Nation of Islam) all congealed under the heading of "Salafiyya," especially in America. While Knight is largely synthesizing the recent work of other scholars (especially Henri Lauzière and David Commins), this chapter is one of the best available sensitive and brief summaries of contemporary scholarship on the origins of twentieth-century Salafism.

The final three chapters (7: "I Was a Teenage Islamist"; 8: "Journey to the End of Coherence: Manhaj of No Manhaj"; 9: "Pilgrims of the Proto-Islamic") generally reprise and remix earlier themes, tying Knight's foregoing analysis to his own journey and nascent reconceptualization of a sensory, experiential, "postauthentic Islam" (339). He takes issue with Hadith-suspicious "Qur'an-only," feminist, and progressive attempts to authoritatively reinterpret Islam, arguing they are making the same mistake as Salafis: attempting to retrieve a coherent, simple, universal vision of Islam that bypasses the messiness and multifariousness of actual Islamic history. $\mathrm{He}$ advocates instead a mystical, rhizomatic, decentered Islam without isnāds linking one to a pristine past or authoritative interpretation. Knight's personal Islam has room for the Five Percenters and the Salafis and the Nation of Islam and drug-induced hallucinations that lead to reinvigorated prayer.

Why I Am a Salafi is certainly not a book for everyone. I suspect that most self-identified Salafis (and, to be fair, most self-identified Muslims) would bristle at Knight's analysis and defense of their movement. His incessant trolling and celebrative heterodoxy give this book a raw, challenging character. He assumes that his audience is conversant enough in Muslim vocabulary that they can follow his digressions into Arabic meanings and Sunni history. He relies heavily on the work of other scholars, an eclectic mix of postmodern literary theorists, Islamicists, historians, and classical Islamic scholars. The autobiographical nature of Knight's reflections intrinsically ties his analysis to his own peculiar life-path. Apart from his very strong composite analysis in chapter 6 of the commingled social and theo- 
logical forces that gave rise to modern Salafism, there is little here that will surprise students of modern Muslim history.

That being said, Why I Am a Salafi makes two major contributions to conversations within and about Islam in the modern world. First, it is a fascinating, experimental text in the burgeoning world of postmodern Islamic literature. Knight's genre-mixing, navel-gazing, theory-laden style pushes the envelope on how Western Muslims grapple personally, literarily, and collectively with shifts in American and European philosophy and culture over the past half century. Knight already has carved out a key role in that developing sub-genre, and this book further demonstrates his unique voice. Second, Why I Am a Salafi highlights the continuing ferment around the term and identity "Salafi." Like Lauzière's recent The Making of Salafism (Columbia University Press, 2016), which is more historical, etymological, and dispassionately analytical, Why I Am a Salafi illustrates just how flexible and malleable the concept of Salafism is. Knight's "Salafism" might be tongue-in-cheek or a rhetorical pose, but his playing on and with the term points to the many contested definitions of who and what count as Salafiyya.

Matthew D. Taylor Professorial Lecturer Department of Theology Georgetown University 